\title{
Variation within service categories and customer satisfaction: A segment-based approach using the tetra-class model
}

Received (in revised form): 23rd October, 2006

\author{
Yannick Poubanne \\ is Associate Director of DBM, a company based in France specialising in database marketing for the vet industry in Europe.
}

\section{Fabrice Clerfeuille}

is Associate Professor of Marketing at the University of Nantes (France).

\section{Jean-Louis Chandon}

is Professor of Marketing at the University of Aix-en-Provence (France), where he leads the research centre on organisations and management (CEROG).

\begin{abstract}
Do client's age, gender or income affect how they may benefit from certain services? Is the classification of a service into one of the four categories of the tetra-class model, fixed or, for example, linked to the length of time a customer has been a client or their geographical proximity? This study examines how the contribution of certain services to customer satisfaction changes in reference to his age, gender and income. Without questioning the suitability of the tetra-class model for classifying services, the authors have studied the nature of the changes in categories of services for three client-based variables and two variables linked to the service relationship. The results indicate that there are degrees of variability that alter in importance from one client segment to another and also with respect to the particular service under consideration.
\end{abstract}

Journal of Targeting, Measurement and Analysis for Marketing (2006) 15, 30-46. doi:10.1057/palgrave.jt.5750032

\section{INTRODUCTION}

Numerous marketing research studies concerning customer satisfaction have been carried out in the service sector. The multiple advantages that customer satisfaction brings to any business make such studies necessary. Indeed, customer satisfaction is one of the key factors for a successful business seeking to diversify within their particular market. ${ }^{1-3}$ There are several stages to understanding the reasons behind customer satisfaction or dissatisfaction. The first stage consists of knowing to what extent each service

\footnotetext{
Correspondence: Yannick Poubanne, University of Aix-Marseille III, IAE, Clos Guiot, BP 33, 13540 Puyricard, France. Tel: 0033608818893 ;

Fax: 0033608819944 ;

E-mail: ypoubanne@wanadoo.fr
}

offered contributes to the level of consumer satisfaction: how can the many variable services be categorised according to their effect on customer satisfaction or dissatisfaction? In the second stage, the variability of categories of service comes into question: is the way in which services are categorised (by their contribution to satisfaction) invariable or a function of the segment of clientele under consideration? The final stage involves the study of changes in service categories: which are the most variable services and which are the most frequent inter-category changes?

Our presentation follows this logical progression by means of a study carried out in the veterinary sector. The veterinary profession was chosen as the study area for certain reasons: complex range of services on offer combining basic services (medical and surgical services) and 
associated services (such as the sale of pet food or pet grooming services for example), stronger and stronger competition and the growing fickleness of pet-owners in their choice of veterinary surgeon, despite their own strong involvement. These characteristics invite a study of the elements of client satisfaction, as a function of segment variables.

\section{CONCEPTUAL VIEW OF SATISFACTION}

Researchers have defined consumer satisfaction in many different ways. The authors perceive that attitudes to satisfaction are an emotional response ${ }^{4}$ or the result of a simultaneously emotional and cognitive process. ${ }^{5}$ Whether a transactional or relational approach is used in a study will influence any conclusions made about satisfaction. ${ }^{6-8}$

For our study, we have used the definitions proposed by Garbarino and Johnson ${ }^{9}$ who see satisfaction as 'either an immediate post-purchase evaluative judgment or an emotional reaction to the firm used for the most recent transaction'.

From multiple research, ${ }^{10-12}$ Llosa $^{13,14}$ demonstrates the fluctuating importance of the various services that contribute to consumer satisfaction; Bartikowski and Llosa ${ }^{15}$ favour the tetra-class model for which they give the following five advantages:

- The weight of services depends on their positive or negative performance.

- The boundaries between categories of services are established clearly and not arbitrarily.

- Data in ordinal form are sufficient to obtain explicit results.

- The tetra-class model allows the development of visual contribution charts.

- The tetra-class model is based on clients own experiences of services and not a simulation.

In this tetra-class model, services are classified into one of four categories, according to the way(s) in which they affect the clients' experiences (Figure 1):

- 'Basic services': These contribute considerably to the clients' overall level of dissatisfaction when they are unfavourably evaluated. When

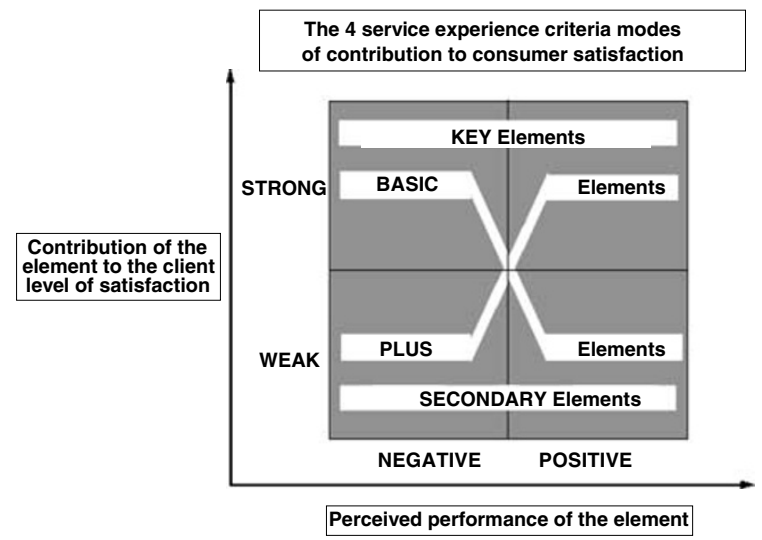

Figure 1: The four ways in which services contribute to client satisfaction (Llosa ${ }^{3}$ )

they are evaluated favourably, however, their contributions are weak to client satisfaction.

- 'Plus services': These contribute considerably to the overall level of client satisfaction when they are favourably evaluated. When they are unfavourably evaluated, their contributions are weak to client's dissatisfaction.

- 'Key services': These contribute considerably to the degree of dissatisfaction or satisfaction of the client, regardless of the type of evaluation by the client.

- 'Secondary services': These do not have a primary role in the level of overall client satisfaction or dissatisfaction, whatever way they are evaluated.

The tetra-class model as tested in a variety of different business sectors, such as automobile finance, catering ${ }^{16}$ and large-scale alimentary distribution, ${ }^{17}$ has also been applied to the health sector. ${ }^{18}$ These studies have shown different ways of categorising the various types of services offered in each segment. Segmentation, sociodemographic and behavioural variations mean that services must be categorised differently according to the segment being studied. ${ }^{19}$ These theories have led us to put forward the following hypotheses.

\section{HYPOTHESES AND METHODOLOGY}

The hypotheses of this research concern the variation in service categories that contribute to 
consumer satisfaction according to the segments of clients under analysis. After presenting the hypotheses, we describe the methods used to test them.

\section{Hypotheses}

Three main groups of hypotheses are proposed to study the variation in service categories that contribute to consumer satisfaction.

The first group of hypotheses concern the variation in service categories with respect to each of the variations in client segment.

Five segmentation variables have been chosen: age of the client, length of time that they have been with the practice, their distance from the clinic, their income and their gender. Age and income have already been tested as moderator of the 'satisfaction-loyalty' relationship by Homburg and Giering. ${ }^{20}$ Similarly, Mittal and Kamakura ${ }^{21}$ have shown that gender, age and area of living influence clients satisfaction. We then have considered that the 'length of time with the practice' was a proxy of client experience with the practice, according to the two experts in the vet profession.

Whether or not the tetra-class category of service changes with each segment will be evaluated as follows:

H1: There is at least one service whose tetra-class category depends on the age of the client.

H2: There is at least one service whose tetra-class category depends on how long the client has been with the clinic.

H3: There is at least one service whose tetra-class category depends on the clinic's proximity to the client.

H4: There is at least one service whose tetra-class category depends on the income of the client.

H5: There is at least one service whose tetra-class category depends on the gender of the client.
The second group of hypotheses involves the variability in service categories for all the five client segments together. We have listed 92 services (Appendix A) that can be subdivided into nine categories as follows: four in relation to the access to the clinic; 15 to the support staff; 19 to the waiting period; four to the exterior of the clinic; four to the financial aspects; seven to the hospitalisation of the animal; 13 to general information; five to the telephone service and; 21 to the veterinary surgeons. We have put forward the hypothesis that the degree of category variation depends on the nature of the service. We will evaluate this as follows:

H6: The variation in tetra-class category depends on the nature of the service.

The third group of hypotheses involves the typology of services as a function of their variability with respect to the different client segments. Certain types of services can be stable, while others can present a considerable category variation depending on the client segment. The hypothesis is therefore as follows:

H7: Services can be grouped according to their degree of category variability.

We then describe the classes of services obtained.

\section{Method}

First, we reiterate reasons for choosing the particular area of study and then go on to describe the techniques used for data collection and finish the methods of data analysis.

\section{Study area}

The area of study chosen is that of the services offered by the companion animal veterinary sector. These include medicine and surgery (with many different levels of expertise, from simple vaccinations through to complex surgery), but also the sale of associated products (flea control, hygiene products, commercial pet foods, etc). These 'side products' can also be purchased by the client in a variety of other outlets like garden centres, pharmacies, pet shops, large and mediumsize supermarkets. The veterinary sector has been 
chosen for certain specific characteristics: great client involvement in animal treatment, complexity of services offered, strong emotional ties between the client, pet and vet, strong competition within the sector (even between colleagues), no fixed fares, co-existence of general practitioners and specialists within the same clinic (chosen freely by the client) and the existence of pet health insurance although under-subscribed by pet owners. For all these reasons, the choice of a veterinary surgeon by a pet owner is often the result of second-hand information from friends and neighbours, with relation to the quality of services on offer from the various clinics. This method of selection engenders a growing nonfidelity among pet owners who are tempted to change veterinary surgeries on an increasingly frequent basis.

\section{Data collection method}

The data was collected in two stages: the first stage was of a qualitative nature, while the second was quantitative.

The qualitative stage was designed to find the services which, in the client's (pet owner's) perception, contributed to the quality of service of a veterinary practice, regardless of the service the client evaluated. Semi-guided interviews were carried out with 18 pet owners and five veterinary surgeons. They were carried out in distinct geographic areas (Nantes, Paris and Nice in France, and London in the UK) to take into account local variations (eg the existence of a car park was of paramount importance to Parisian clients but was not even mentioned by provincial clients), without necessarily questioning the models chosen by individuals. During this phase, 92 services were selected and regrouped into nine distinct categories: access to the clinic, the support staff, the waiting period, the exterior of the clinic, the financial aspects, the hospitalisation of the animal, the general information, the telephone service and the veterinary surgeons (cf list of services used, Appendix A).

The second, or quantitative stage, consisted of handing out questionnaires to pet owners during their consultation in a veterinary clinic. Each of the 92 services was evaluated by the respondents on a performance scale from 1 to 6 . Four hundred and ninety-three questionnaires were voluntarily returned during the year 2001 from four French veterinary clinics and one English clinic.

'Overall satisfaction' was measured on a semantic scale from 1 to 10 points.

We singled out six groups in the age of the respondent category: less than 20 years old, 20-29 years old, 30-39 years old, 40-49 years old, 50-59 years old, 60 years old and above.

The monthly income of the respondent allowed us to single out four population groups: less than $\$ 1500, \$ 1500-3000, \$ 3000-4500$, and more than $\$ 4500$.

Four groups were derived from the client's home distance to the clinic: less than 1 mile, $1-5$ miles, 6-10 miles, more than 10 miles.

Each client was also asked to indicate how long he had been attending the clinic. Six groups were assigned: less than 1 year, 1 year, 2 years, 3 years, 4 years, 5 years or more. The choice of these intervals was determined by taking into account the specific nature of this sector in relation to the annual booster vaccinations given to pets.

After eliminating all those questionnaires which were incomplete, 267 questionnaires were analysed. The characteristics of our study population are displayed in Appendix B.

\section{Data analysis}

The technique of data analysis that was used for the categorisation of services is that of correspondence analysis, as proposed by Llosa. ${ }^{22}$ The perceived performances of the 92 different services were first dichotomised in an asymmetrical way (responses from 1 to 4 in the first part and 5 to 6 in the second part) in order to make a clear distinction between 'positive' responses and those which we designated as 'negative'. The satisfaction scores were also regrouped into two modalities, termed 'positive score' and 'negative score'. For this last variable, the dividing point was identified using C\&RT segmentation. This technique is very close to the AID method, and the binary algorithm C\&RT ${ }^{23}$ identifies homogenous sub-groups by producing exactly two nodes by division. 
A correspondence analysis is then applied on two variables. One, made up of the two modalities of each service (positive and negative evaluation), has 184 modalities (92 services $\times 2$ modalities). The other, satisfaction, has two modalities (either a positive or a negative score). The resulting axis is therefore one-dimensional and recreates 100 per cent of the initial variation.

Each service can therefore be attributed two factorial scores (the first score corresponding to the negative evaluations, and the second to the positive ones) for the variable of satisfaction. The horizontal axis of the factorial chart represents the contribution of the service to overall satisfaction when it is evaluated positively.

As a function of their position with respect to this reference mark, the services are categorised according to the terminology of Llosa, ${ }^{24}$ into four categories: 'Basic criteria', 'Key criteria', 'Plus criteria' and 'Secondary criteria' (cf Figure 1).

In order to test our hypotheses, the whole sample group was used to evaluate overall client satisfaction, and then each client segment was studied individually. The segments studied correspond to the age of the respondent (one segment for under 50 years old and one for over 50 years), the gender (male or female), the level of monthly income (less than $\$ 1500$ and more than $\$ 1500)$, the distance of the client from the clinic (less than 5 miles and more than 5 miles) and finally the client's seniority in the practice (less than 5 years and more than 5 years). For each segment variable, a separate scatter graph was drawn, with the services placed into categories according to their coordinates on the axis of satisfaction of negatively evaluated services (X-axis) and their coordinates on the axis of positively evaluated services (Y-axis). An example of two of these charts that were obtained for the segment variable 'age of client' can be found in Appendix C (categorisation of services for clients aged over 50 years and those aged under 50 years).

To validate the first group of hypotheses concerning the category variability of services within each segment variable (hypotheses 1-5), we established a table showing distribution of each of the 92 services between the four categories of tetra-class models. If the segment variable has no effect on the service category, then all the services will be categorised in an identical manner and will therefore be placed on the diagonal of the table. If the two modalities of the segment variable have an effect, then some of the services will be classified differently. The more the degree of association differs from 100 per cent, the more services there are that change tetra-class category according to the segment variable. In the extreme, an absence of association, validated by the Fisher test (chosen to free us from the constraint of having to have five theoretical observations in at least 20 per cent of the cells), would render the tetra-class model obsolete. In fact, if the categorisation of services changes to the extent of being independent from one segment variable modality to another, then the tetra-class model of categorisation becomes completely unstable and has no purpose. We predict a strong stability of the tetra-class model, as shown by a rejection of the independency hypothesis. We, however, expect to find that the segment variables have an effect that is manifested by limited, but significant transfers of a certain number of services from one category to another. We are testing the significance of such transfers by the statistic of best fit. This statistic, calculated by SPSS, is interpreted in terms of standard deviations: values above 2.5 corresponding to a significant transfer. We then place the modalities of the five segment variables in the space of the four modes of contribution to satisfaction in order to obtain a synthetic vision of the effects of segment allocation.

To validate hypothesis 6 , we use the analysis of variation, in order to examine the mean degree of variation of category according to the nature of the service. If we reject the independency hypothesis, we will establish, among the nine categories of service, those whose category variability is the most pronounced.

\section{RESULTS}

The synthesis of service category variations appears in Table 1. The services are in the left hand column and the two modalities used for each of the five client segments are in the 
Table 1: Variation in category of services in relation to the client segments under consideration

\begin{tabular}{|c|c|c|c|c|c|c|c|c|c|c|c|}
\hline elem & SERVICE & $\mathrm{ECH}$ & $\begin{array}{l}\text { Age }<50 \\
\text { years }\end{array}$ & $\begin{array}{l}\text { Age }>50 \\
\text { years }\end{array}$ & $\begin{array}{l}\text { Loy<5 } \\
\text { years }\end{array}$ & $\begin{array}{l}\text { Loy }>5 \\
\text { years }\end{array}$ & $\begin{array}{l}\text { Dis }<5 \\
\text { miles }\end{array}$ & $\begin{array}{l}\text { Dis }>5 \\
\text { miles }\end{array}$ & \begin{tabular}{|l|l|} 
Inc $<$ & Inc $>$ \\
1500 & 1500 \\
USD & USD \\
\end{tabular} & $\begin{array}{l}\text { Sex : } \\
\text { Fem }\end{array}$ & $\begin{array}{l}\text { Sex : } \\
\text { Mal }\end{array}$ \\
\hline ac_fac & Access: ease of parking close to the clinic & SEC & SEC & SEC & SEC & SEC & SEC & SEC & BAS SEC & SEC & SEC \\
\hline ac_ind & Access: signs indicating the way to the clinic & SEC & BAS & SEC & BAS & SEC & BAS & SEC & SEC BAS & SEC & CLE \\
\hline ac_rap & Access: ease and speed of access to the clinic & BAS & BAS & BAS & BAS & BAS & BAS & SEC & SEC BAS & SEC & \\
\hline ac_sec & Access: safety of car park for my animal & SEC & SEC & SEC & SEC & BAS & SEC & SEC & BAS SEC & SEC & SEC \\
\hline as_aff & Staff: affection towards my pet & BAS & BAS & BAS & BAS & BAS & BAS & BAS & \begin{tabular}{|l|l|} 
BAS & BAS \\
\end{tabular} & BAS & BAS \\
\hline as_amo & Staff: love of animals & BAS & BAS & BAS & BAS & BAS & BAS & BAS & SEC BAS & $\mathrm{BAS}$ & BAS \\
\hline as_bad & Staff: whether they wear name badges & BAS & BAS & SEC & BAS & BAS & SEC & BAS & SEC BAS & BAS & $S$ SEC \\
\hline as_com & Staff: commercial competence & BAS & BAS & BAS & BAS & BAS & BAS & BAS & BAS BAS & BAS & BAS \\
\hline as_dos & Staff: access to the clinical recor & BAS & BAS & SEC & BAS & BAS & SEC & BAS & BAS BAS & BAS & BAS \\
\hline as_dou & Staff: kindness towards my pet & BAS & BAS & BAS & BAS & BAS & BAS & BAS & \begin{tabular}{|l|l|} 
BAS & BAS \\
\end{tabular} & BAS & BAS \\
\hline as_eco & Staff: ability to listen & BAS & BAS & BAS & BAS & BAS & BAS & SEC & \begin{tabular}{ll|} 
BAS & BAS \\
\end{tabular} & BAS & \\
\hline as_int & Staff: interest in my animal & BAS & BAS & BAS & BAS & BAS & BAS & BAS & BAS BAS & BAS & BAS \\
\hline as_pat & Staff: patience & BAS & BAS & BAS & BAS & BAS & BAS & BAS & BAS BAS & BAS & \\
\hline as_pol & Staff: politeness & BAS & BAS & BAS & BAS & BAS & BAS & BAS & \begin{tabular}{|l|l|} 
BAS & BAS \\
\end{tabular} & BAS & \\
\hline as_pre & Staff: always available at reception & BAS & BAS & BAS & BAS & BAS & BAS & BAS & \begin{tabular}{|l|l|} 
BAS & BAS \\
\end{tabular} & BAS & $\mathrm{BA}$ \\
\hline as_pro & Staff: appropriate and clean clothing & BAS & BAS & BAS & BAS & BAS & BAS & BAS & BAS BAS & BAS & BAS \\
\hline as_ras & Staff: reassurance & BAS & BAS & BAS & BAS & BAS & BAS & BAS & \begin{tabular}{|l|l|} 
BAS & BAS \\
\end{tabular} & BAS & BAS \\
\hline as_sou & Staff: smiles & BAS & BAS & BAS & BAS & BAS & BAS & SEC & \begin{tabular}{l|l|} 
BAS & BAS \\
\end{tabular} & BAS & \\
\hline as_tec & Staff: technical competence & BAS & BAS & BAS & BAS & BAS & BAS & BAS & BAS BAS & BAS & BAS \\
\hline at_aff & Waiting area: posters & BAS & BAS & SEC & BAS & BAS & BAS & BAS & BAS BAS & BAS & BAS \\
\hline at_bru & Waiting area: noise levels & SEC & SEC & SEC & SEC & SEC & SEC & SEC & SEC SEC & SEC & \\
\hline at_cla & Waiting area: lighting of the waitir & BAS & BAS & SEC & SEC & BAS & BAS & BAS & \begin{tabular}{|l|l|} 
BAS & BAS \\
\end{tabular} & BAS & BAS \\
\hline at_con & Waiting area: comfort of chairs & SEC & SEC & SEC & SEC & PLU & SEC & CLE & PLU SEC & SEC & SEC \\
\hline at_dec & Waiting area: decor & CLE & CLE & SEC & BAS & CLE & CLE & BAS & CLE SEC & CLE & SEC \\
\hline at_del & Waiting area: information about delays & PLU & PLU & SEC & CLE & SEC & PLU & CLE & SEC CLE & PLU & J BAS \\
\hline at_dis & Waiting area: availability of chairs & CLE & SEC & CLE & SEC & CLE & SEC & CLE & CLE SEC & CL] & SEC \\
\hline at_enf & Waiting area: special area for children & PLU & PLU & SEC & PLU & SEC & SEC & PLU & PLU SEC & PI I & J SEC \\
\hline at_inf & Waiting area: information on products and services & SEC & BAS & SEC & SEC & SEC & BAS & SEC & BAS SEC & SEC & BAS \\
\hline at_iso & Waiting area: possibility to get away from other clients & SEC & PLU & SEC & SEC & PLU & SEC & PLU & PLU SEC & SEC & SEC \\
\hline at_mus & Waiting area: ambient music & PLU & PLU & SEC & PLU & PLU & PLU & PLU & SEC PLU & PLU & $\mathrm{J}$ SEC \\
\hline at_occ & Waiting room: things to do & SEC & SEC & SEC & SEC & SEC & SEC & PLU & \begin{tabular}{|l|l|} 
SEC & SEC \\
\end{tabular} & PLU & J SEC \\
\hline at_ode & Waiting area: oc & BAS & BAS & BAS & BAS & BAS & BAS & BAS & SEC BAS & BAS & BAS \\
\hline at_pon & Waiting area: punctuality & SEC & SEC & SEC & SEC & SEC & BAS & SEC & CLE SEC & SEC & BAS \\
\hline at_pro & Waiting area: cleanliness & BAS & SEC & BAS & $\mathrm{SEC}+\mathrm{M} 1$ & BAS & SEC & BAS & SEC BAS & SEC & BAS \\
\hline at_rev & Waiting area: magazines available & SEC & PLU & SEC & SEC & SEC & SEC & CLE & PLU SEC & PLU & J SEC \\
\hline at_tab & Waiting area: notice board with small ads & SEC & SEC & SEC & SEC & BAS & $\mathrm{BAS}$ & SEC & BAS SEC & SEC & SEC \\
\hline at_tem & Waiting area: time spent waiting & SEC & SEC & SEC & BAS & SEC & CLE & SEC & CLE SEC & SEC & BAS \\
\hline at_tmp & Waiting area: temperature & BAS & BAS & SEC & SEC & BAS & SEC & BAS & BAS SEC & BAS & S SEC \\
\hline ex_ass & Exterior: possibility of waiting outside & BAS & BAS & BAS & BAS & BAS & BAS & BAS & BAS BAS & SEC & CLE \\
\hline ex_heu & Exterior: clear indication of opening and closing times & BAS & BAS & BAS & BAS & BAS & BAS & BAS & BAS BAS & BAS & BAS \\
\hline ex_pro & Exterior: cleanliness of the entrance area & BAS & BAS & BAS & BAS & BAS & BAS & BAS & BAS BAS & $+\infty$ & BAS \\
\hline ex_spe & Exterior: Indication of names and specialisations of vets & BAS & BAS & BAS & BAS & BAS & BAS & CLE & SEC CLE & BAS & S CLE \\
\hline fi_cla & Financial: clarity of the bill & BAS & BAS & BAS & BAS & BAS & CLE & BAS & \begin{tabular}{l|l|} 
BAS & BAS \\
\end{tabular} & BAS & BAS \\
\hline fi_dev & Financial: quote before treatment / hospitalisation & BAS & BAS & SEC & CLE & BAS & CLE & SEC & BAS BAS & BAS & BAS \\
\hline fi_exp & Financial: explications at the time of payment & BAS & BAS & BAS & BAS & BAS & CLE & BAS & BAS BAS & BAS & BAS \\
\hline fi_rqp & Financial: price vs. quality of the clinic & BAS & $\mathrm{CLE}$ & SEC & CLE & BAS & CLE & BAS & CLE BAS & BAS & S CLE \\
\hline
\end{tabular}


Table 1: Continued

\begin{tabular}{|c|c|c|c|c|c|c|c|c|c|c|c|c|}
\hline elem & SERVICE & $\mathrm{ECH}$ & $\begin{array}{l}\text { Age }<50 \\
\text { years }\end{array}$ & $\begin{array}{l}\text { Age }>50 \\
\text { years }\end{array}$ & $\begin{array}{l}\text { Loy<5 } \\
\text { years }\end{array}$ & $\begin{array}{l}\text { Loy }>5 \\
\text { years }\end{array}$ & $\begin{array}{l}\text { Dis }<5 \\
\text { miles }\end{array}$ & $\begin{array}{l}\text { Dis }>5 \\
\text { miles }\end{array}$ & $\begin{array}{l}\text { Inc }< \\
1500 \\
\text { USD } \\
\end{array}$ & \begin{tabular}{|l|} 
Inc> \\
1500 \\
USD \\
\end{tabular} & $\begin{array}{l}\text { Sex : } \\
\text { Fem }\end{array}$ & $\begin{array}{l}\text { Sex : } \\
\text { Mal }\end{array}$ \\
\hline ho_cla & Hospitalisation: clarity of discharge instructions & BAS & BAS & BAS & BAS & BAS & BAS & BAS & BAS & & BAS & BAS \\
\hline ho_con 1 & Hospitalisation: the animal's comfort & BAS & BAS & BAS & BAS & BAS & BAS & SEC & CLE & BAS & $\mathrm{BAS}$ & BAS \\
\hline ho_evo 1 & Hospitalisation: updates about my pets health & BAS & BAS & BAS & BAS & BAS & BAS & BAS & BAS & & BAS & BAS \\
\hline ho_ras 1 & Hospitalisation: reassurance & BAS & BAS & BAS & BAS & BAS & BAS & BAS & BAS & & BAS & BAS \\
\hline ho_sui 1 & Hospitalisation: follow up of the case & BAS & BAS & BAS & BAS & BAS & BAS & BAS & BAS & BAS & BAS & BAS \\
\hline ho_tel & Hospitalisation: updates by phone & BAS & BAS & BAS & BAS & BAS & BAS & BAS & BAS & & BAS & BAS \\
\hline ho_vis 1 & Hospitalisation: opportunity to visit the animal & BAS & BAS & SEC & BAS & BAS & BAS & BAS & SEC & BAS & BAS & S SEC \\
\hline in_acq & Information: re acquiring a pet & CLE & CLE & SEC & PLU & BAS & SEC & CLE & SEC & CLE & $\mathrm{BAS}$ & CLE \\
\hline in_ass & Information: re pet insurance & SEC & SEC & SEC & SEC & SEC & SEC & SEC & SEC & BAS & SEC & CLE \\
\hline in_ele & Information: re training my pet & BAS & BAS & SEC & SEC & BAS & SEC & BAS & SEC & $\mathrm{BA}$ & BAS & SEC \\
\hline in_gar & Information: re kennels and boarding for my pet & PLU & PLU & PLU & PLU & CLE & PLU & CLE & PLU & CLE & CLE & PLU \\
\hline in_inf & Information: personnal information & CLE & CLE & CLE & PLU & CLE & CLE & CLE & CLE & CLE & CLE & CLE \\
\hline in_mor 1 & Information: re the death of my pet & CLE & CLE & PLU & SEC & CLE & SEC & CLE & CLE & CLE & CLE & PLU \\
\hline in_nou & Information: re new products and services & BAS & CLE & SEC & CLE & BAS & BAS & BAS & CLE & BAS & BAS & CLE \\
\hline in_per 1 & Information: lost animals & SEC & CLE & SEC & SEC & BAS & SEC & SEC & SEC & BAS & SEC & CLE \\
\hline in_pro & Information: re products sold in the clinic & BAS & BAS & SEC & BAS & SEC & BAS & SEC & BAS & SE & BAS & SEC \\
\hline in_sai & Information: breeding from my pet & CLE & CLE & BAS & PLU & CLE & PLU & CLE & CLE & & CLE & PLU \\
\hline in_ser & Information: re services offered by the clinic & BAS & BAS & BAS & BAS & BAS & BAS & BAS & BAS & & BAS & BAS \\
\hline in_spe & Information: specialisations available at the clinic & CLE & CLE & SEC & SEC & CLE & SEC & CLE & CLE & $\mathrm{SE}$ & CLE & SEC \\
\hline in_voy 1 & Information: travelling with my pet & CLE & CLE & CLE & CLE & CLE & CLE & CLE & PLU & & $\mathrm{CLE}$ & CLE \\
\hline te_cla & Telephone: clarity of answers to my questions & BAS & BAS & BAS & BAS & BAS & BAS & BAS & BAS & & BAS & BAS \\
\hline te_dis & Telephone: ease of getting through & BAS & BAS & BAS & BAS & BAS & BAS & SEC & BAS & BAS & SEC & BAS \\
\hline te_rap & Telephone: call me back if not available & BAS & BAS & BAS & BAS & BAS & BAS & BAS & BAS & BAS & BAS & BAS \\
\hline te_rdv & Telephone: getting a convenient consultation time & BAS & BAS & BAS & BAS & BAS & BAS & BAS & BAS & & BAS & BAS \\
\hline te_rpi & Telephone: speed of response & SEC & SEC & BAS & SEC & BAS & BAS & SEC & SEC & BAS & SEC & BAS \\
\hline ve_aff & Veterinary: affection for my pet & BAS & BAS & BAS & BAS & BAS & BAS & BAS & BAS & BAS & BAS & BAS \\
\hline ve_amo & Veterinary: love of animals & BAS & BAS & BAS & BAS & BAS & BAS & BAS & SEC & BAS & BAS & BAS \\
\hline ve_arg & Veterinary: balance between money and love for animal & BAS & BAS & BAS & BAS & BAS & BAS & BAS & BAS & & BAS & BAS \\
\hline ve_cho & Veterinary: see the veterinary surgeon of my choice & SEC & SEC & BAS & BAS & SEC & SEC & SEC & SEC & BAS & SEC & SEC \\
\hline ve_cla & Veterinary: clarity of explanations & BAS & BAS & BAS & BAS & BAS & BAS & BAS & BAS & BAS & BAS & BAS \\
\hline ve_com & Veterinary: commercial competence & BAS & BAS & BAS & BAS & BAS & BAS & BAS & BAS & BAS & BAS & BAS \\
\hline ve_con & Veterinary: advice about the health of my pet & BAS & BAS & BAS & BAS & BAS & BAS & SEC & SEC & BAS & BAS & BAS \\
\hline ve_dev & Veterinary: devotion to my animal & BAS & BAS & BAS & BAS & BAS & BAS & BAS & BAS & BAS & BAS & BAS \\
\hline ve_dia & Veterinary: accuracy of diagnosis & BAS & BAS & BAS & BAS & BAS & BAS & BAS & BAS & BAS & BAS & BAS \\
\hline ve_dou & Veterinary: gentle ness with my animal & BAS & BAS & BAS & BAS & BAS & BAS & BAS & BAS & BAS & BAS & BAS \\
\hline ve_gue & Veterinary: speed of recovery of my pet & BAS & BAS & BAS & BAS & BAS & BAS & BAS & BAS & BAS & BAS & BAS \\
\hline ve_hon & Veterinary: honesty & BAS & BAS & BAS & BAS & BAS & BAS & BAS & BAS & BAS & BAS & BAS \\
\hline ve_inf & Veterinary: interest to help me decide & BAS & BAS & BAS & BAS & BAS & BAS & BAS & BAS & BAS & BAS & BAS \\
\hline ve_int & Veterinary: interest in my pet & BAS & BAS & BAS & BAS & BAS & BAS & BAS & BAS & BAS & BAS & BAS \\
\hline ve_jus & Veterinary: speed of diagnosis & BAS & BAS & BAS & BAS & BAS & BAS & BAS & BAS & BAS & BAS & BAS \\
\hline ve_pol & Veterinary: politeness & BAS & BAS & BAS & BAS & BAS & BAS & BAS & BAS & BAS & BAS & BAS \\
\hline ve_pro & Veterinary: cleanliness & BAS & BAS & BAS & BAS & BAS & BAS & BAS & BAS & BAS & BAS & BAS \\
\hline ve_ras & Veterinary: reassurance & BAS & BAS & BAS & BAS & BAS & BAS & BAS & BAS & BAS & BAS & BAS \\
\hline ve_sou & Veterinary: pleasant disposition & BAS & BAS & BAS & BAS & BAS & BAS & BAS & BAS & BAS & BAS & BAS \\
\hline ve_tec & Veterinary: technical competence & BAS & BAS & BAS & BAS & BAS & BAS & BAS & BAS & BAS & BAS & BAS \\
\hline ve_tem & Veterinary: time spent in consultation & BAS & BAS & BAS & BAS & BAS & BAS & BAS & BAS & BAS & BAS & BAS \\
\hline
\end{tabular}

KEY (tetra-class categories of service): SEC, Secondary service; PLU, Plus service; BAS, Basic service; KEY=Key service. 
column headings. The column entitled ' $\mathrm{ECH}$ ' gives the categories that were most frequently allocated to each service by all 267 respondents, viewing the sample group as a whole. Each of the cells in the table contains one of the four tetraclass model categories; thus, each service has a category allocated to it for both modalities of each of the five different client segment variables. The cells with a dark background correspond to a difference in service categorisation between the two modalities of the same segment variable. The cells with a white background show identical service categorisation for both modalities of a segment variable. In other words, if two cells are belonging to the same dichotomised variable and are displaying different service categorisation these are darkened, whitened otherwise.

Analysis of Table 1 indicates that differences in categorisation affect particular categories of service more than others. For example, there are more differences for those services in the "waiting area' criteria (prefix 'att') or for those concerned with 'information available in the clinic' (prefix 'in') than for the other service categories. This is what we want to quantify in testing our hypotheses.

\section{First group hypotheses test (category variation of services within the same client segment variable)}

Table 2 creates, for each segment variable studied, the percentage of differences in service categorisation.

There are more category transfers in the variables 'income' and 'distance from the clinic' with 41.30 and 39.13 per cent, respectively. There are, however, fewer category transfers of services for the variables 'Age' and 'Time as a client'. It appears that category transfers occur more commonly for segment variables that are associated with 'access to services' than for those of 'individual or relationship' nature. These results support our first group of hypotheses, comprising $\mathrm{H} 1, \mathrm{H} 2, \mathrm{H} 3, \mathrm{H} 4$ and $\mathrm{H} 5$. Now, we will examine the detail of the differences in categorisation.

\section{Age influencing the tetra-class categorisation (Table 3 )}

With an exact Fisher test of 50.179, the independency hypothesis can be discarded. We can see that 64 services out of a total of $92(69.2$ per cent) do not change category with the age of the client. The tetra-class model for classification therefore remains significant, with a Phi association of 0.77 (Phi=square root of Khi2 size of sample). Those services classed as 'Basic' by those under 50 years old are, however, more numerous (63) than those so classed by the over 50 s (56). Eleven services classed as 'Basic' by the under 50s, become 'Secondary' for the over 50s; six services classed as 'Key' become 'Secondary' and five services classed 'Plus' become 'Secondary'. These transfers are significant, with a best fit of more than 2.5 SDs.

Table 2: Percentage of service tetra-class category transfers for each segment variable

\begin{tabular}{ll}
\hline Segment variable & $\begin{array}{l}\text { \% of category } \\
\text { transfers }\end{array}$ \\
\hline Age & 30.43 \\
Time as a client & 29.35 \\
Distance from clinic & 39.13 \\
Income & 41.30 \\
Gender & 33.70 \\
\hline
\end{tabular}

Table 3: Effect of client age on the categorisation of services

\begin{tabular}{|c|c|c|c|c|c|}
\hline & \multicolumn{5}{|c|}{ More than 50 years old } \\
\hline & Basic & Key & Plus & Secondary & Total \\
\hline \multicolumn{6}{|c|}{ Less than 50 years old } \\
\hline Basic & 52 & - & - & 11 & 63 \\
\hline Key & 1 & 2 & 1 & 6 & 10 \\
\hline Plus & - & - & 1 & 5 & 6 \\
\hline Secondary & 3 & 1 & - & 9 & 13 \\
\hline Total & 56 & 3 & 2 & 31 & 92 \\
\hline
\end{tabular}


Client seniority in relation to the tetra-class categorisation (Table 4)

With an exact Fisher test of 39.011, the independency hypothesis can be rejected. We can see that 65 services out of a total of 92 (70.7 per cent) do not change category with the length of time that a client has been with the practice. The tetra-class classification therefore remains significant with a phicoefficient of 0.68 . The services classed as 'Basic' by the recent clients (less than 5 years), are, however, less numerous than those classed 'Basic' by the older clients (68), whereas eight services classed 'Secondary' by recent clients become 'Basic' for the older clients. This transfer is significant with a best fit of 3.9 SDs.

\section{Clinic remoteness effect on tetra- class categorisation (Table 5)}

With an exact Fisher test of 41.880, the independency hypothesis can be rejected. We can see that 56 services out of a total of 92 (60.9 per cent) do not change category with the distance of a client from the clinic. The tetra-class classification therefore remains significant with a Phi-coefficient of 0.71 . Twelve services classed as 'Basic' by the closer clients (less than $5 \mathrm{~km}$ ) are, however, classed 'Secondary' by the more distant clients. This transfer is significant with a best fit of 2.8 SDs.

\section{Client income effect on tetra-class categorisation (Table 6)}

With an exact Fisher test of 42.125 , the independency hypothesis can be rejected. There

Table 4: Effect of time at the clinic on the categorisation of services

\begin{tabular}{llllll}
\hline \multicolumn{5}{c}{ Client for more than five years } \\
\cline { 2 - 6 } & Basic & Key & Plus & Secondary & Total \\
\hline Client for less than five years & 56 & 1 & - & 4 & 61 \\
Basic & 3 & 1 & - & 1 & 5 \\
Key & 1 & 3 & 1 & 1 & 6 \\
Plus & 8 & 3 & 2 & 13 & 92 \\
Secondary & 68 & 8 & 3 & & \\
Total & & & & & \\
\hline
\end{tabular}

Table 5: Effect of distance from the clinic on the categorisation of services

\begin{tabular}{|c|c|c|c|c|c|}
\hline & \multicolumn{5}{|c|}{ Client living more than 5 miles from clinic } \\
\hline & Basic & Key & Plus & Secondary & Total \\
\hline \multicolumn{6}{|c|}{ Client less than 5 miles away } \\
\hline Basic & 47 & 1 & - & 12 & 60 \\
\hline Key & 4 & 2 & - & 2 & 8 \\
\hline Plus & - & 3 & 1 & - & 4 \\
\hline Secondary & 5 & 6 & 3 & 6 & 20 \\
\hline Total & 56 & 12 & 4 & 20 & 92 \\
\hline
\end{tabular}

Table 6: Effect of client income on the categorisation of services

\begin{tabular}{|c|c|c|c|c|c|}
\hline & \multicolumn{5}{|c|}{ >1500 \$/month } \\
\hline & Basic & Key & Plus & Secondary & Total \\
\hline \multicolumn{6}{|l|}{$<1500 \$ /$ month } \\
\hline Basic & 49 & - & - & 6 & 55 \\
\hline Key & 3 & 3 & - & 5 & 11 \\
\hline Plus & - & 2 & - & 4 & 6 \\
\hline Secondary & 14 & 3 & 1 & 2 & 20 \\
\hline Total & 66 & 8 & 1 & 17 & 92 \\
\hline
\end{tabular}


are 54 services out of a total of 92 (58.7 per cent) that do not change category with respect to the level of income of the client. The tetra-class model of classification therefore remains significant with a phi-coefficient of 0.67 . The number of basic services increases from 55 to 66 when we go from those clients on a low level of income to those with a high income. In the same way, 14 services classed 'Secondary' by low income clients become 'Basic' services to those with a higher income (over $\$ 1500$ per month).

\section{Client gender effect on tetra-class categorisation (Table 7)}

With an exact Fisher test of 47.504, the independency hypothesis can be rejected. There are 61 services out of a total of 92 (66.3 per cent) that do not change category with respect to the gender of the client. The tetra-class model of classification therefore remains significant with a phi-coefficient of 0.85. Five services classed as 'Basic' by the female clients were classed 'Secondary' by the men. Inversely, seven other services were classed 'Basic' by the males and 'Secondary' by females. These two transfers are significant with best fits of 4.1 and 2.6SDs.

In order to obtain a synthetic view of the relationship between the ten segment variables (five segment variables of two modalities) and the tetra-class model of categorisation, we have carried out an analysis of connections in Table 8: comparing the four ways in which the services contribute to customer satisfaction with the five segment variables and their modalities.

The relationship between the tetra-class category and the segment is low and insignificant $\left(\chi^{2}=29.5, p=0.34\right)$, which proves the stability of the tetra-class system of categorisation. Three factors can be extracted, but the first two factors, which give 84 per cent of the total variation, are sufficient to place the segments in relation to the four methods of contribution to overall satisfaction (Table 9).

Figure 2 shows that the 'Secondary' services oppose the 'Key' services and 'Plus' services on axis 1 . We can therefore call this axis 'importance of contribution' to customer satisfaction. This is the predominant axis, with 58 per cent of the variation. It opposes those services, which always contribute considerably ('Key') against those which never contribute considerably ('Secondary'), whatever their value. The 'Basic' services oppose the 'Plus' services on axis 2 , which only represents 26 per cent of the variation. It is the axis of variable importance. The 'Basic' services contribute negatively and considerably, but only when they are evaluated negatively. The 'Plus' services contribute positively and considerably, but only when they are evaluated positively (Table 10).

The segment variable based on age of client is very closely correlated to the axis of importance of contribution. The younger clients have more 'Basic' and 'Key' criteria than the older clients, who are characterised by a relative predominance of 'Secondary' criteria. The clients who have been with the clinic for longer have a higher percentage of 'Basic' criteria, while the more recent clients have more 'Secondary' criteria. Those clients with a high income have more 'Basic' criteria, while the less well-off clients have more 'Key' and 'Plus' criteria. The effect of income is significantly correlated to axis 2 , which is the axis of variable importance. The effect of gender is marginal (Table 11).

Table 7: Effect of gender on categorisation of services

\begin{tabular}{|c|c|c|c|c|c|}
\hline & \multicolumn{5}{|l|}{ Males } \\
\hline & Basic & Key & Plus & Secondary & Total \\
\hline \multicolumn{6}{|l|}{ Females } \\
\hline Basic & 52 & 4 & - & 5 & 61 \\
\hline Key & - & 2 & 3 & 3 & 8 \\
\hline Plus & 1 & - & - & 4 & 5 \\
\hline Secondary & 7 & 4 & - & 7 & 18 \\
\hline Total & 60 & 10 & 3 & 19 & 92 \\
\hline
\end{tabular}


Table 8: Effect of segment variables on categorisation

\begin{tabular}{|c|c|c|c|c|c|c|}
\hline \multirow[b]{2}{*}{ Segment } & \multicolumn{6}{|c|}{ Tetra-class category } \\
\hline & Modality & Basic & Key & Plus & Secondary & Total \\
\hline Age & $\begin{array}{l}<50 \text { years } \\
50 \text { years }+\end{array}$ & $\begin{array}{l}63 \\
56\end{array}$ & $\begin{array}{r}10 \\
3\end{array}$ & $\begin{array}{l}6 \\
2\end{array}$ & $\begin{array}{l}13 \\
31\end{array}$ & $\begin{array}{l}92 \\
92\end{array}$ \\
\hline Time as client & $\begin{array}{l}<5 \text { years } \\
>5 \text { years }\end{array}$ & $\begin{array}{l}61 \\
68\end{array}$ & $\begin{array}{l}5 \\
8\end{array}$ & $\begin{array}{l}6 \\
3\end{array}$ & $\begin{array}{l}20 \\
13\end{array}$ & $\begin{array}{l}92 \\
92\end{array}$ \\
\hline Distance & $\begin{array}{l}<5 \text { miles } \\
>5 \text { miles }\end{array}$ & $\begin{array}{l}60 \\
56\end{array}$ & $\begin{array}{r}8 \\
12\end{array}$ & $\begin{array}{l}4 \\
4\end{array}$ & $\begin{array}{l}20 \\
20\end{array}$ & $\begin{array}{l}92 \\
92\end{array}$ \\
\hline Income & $\begin{array}{l}<1500 \$ \\
>1500 \$\end{array}$ & $\begin{array}{l}55 \\
66\end{array}$ & $\begin{array}{r}11 \\
8\end{array}$ & $\begin{array}{l}6 \\
1\end{array}$ & $\begin{array}{l}20 \\
17\end{array}$ & $\begin{array}{l}92 \\
92\end{array}$ \\
\hline Gender & $\begin{array}{l}\text { Male } \\
\text { Female } \\
\text { Total }\end{array}$ & $\begin{array}{r}61 \\
60 \\
606\end{array}$ & $\begin{array}{r}8 \\
10 \\
83\end{array}$ & $\begin{array}{r}5 \\
3 \\
40\end{array}$ & $\begin{array}{r}18 \\
19 \\
191\end{array}$ & $\begin{array}{r}92 \\
92 \\
920\end{array}$ \\
\hline
\end{tabular}

Table 9: Extracted variation

\begin{tabular}{|c|c|c|c|c|c|c|}
\hline \multirow[t]{2}{*}{ Dimension } & \multirow[t]{2}{*}{ Singular value } & \multirow[t]{2}{*}{ Inertia } & \multirow[t]{2}{*}{$\chi^{2}$} & \multirow[t]{2}{*}{ Sig. } & \multicolumn{2}{|c|}{ Proportion of inertia } \\
\hline & & & & & Accounted for & Cumulative \\
\hline 1 & 0.136 & 0.019 & & & 0.581 & 0.581 \\
\hline 2 & 0.091 & 0.008 & & & 0.257 & 0.838 \\
\hline 3 & 0.072 & 0.005 & & & 0.162 & 1.000 \\
\hline Total & & 0.032 & 29.452 & $0.339^{*}$ & 1.000 & 1.000 \\
\hline
\end{tabular}

*27 degrees of freedom.

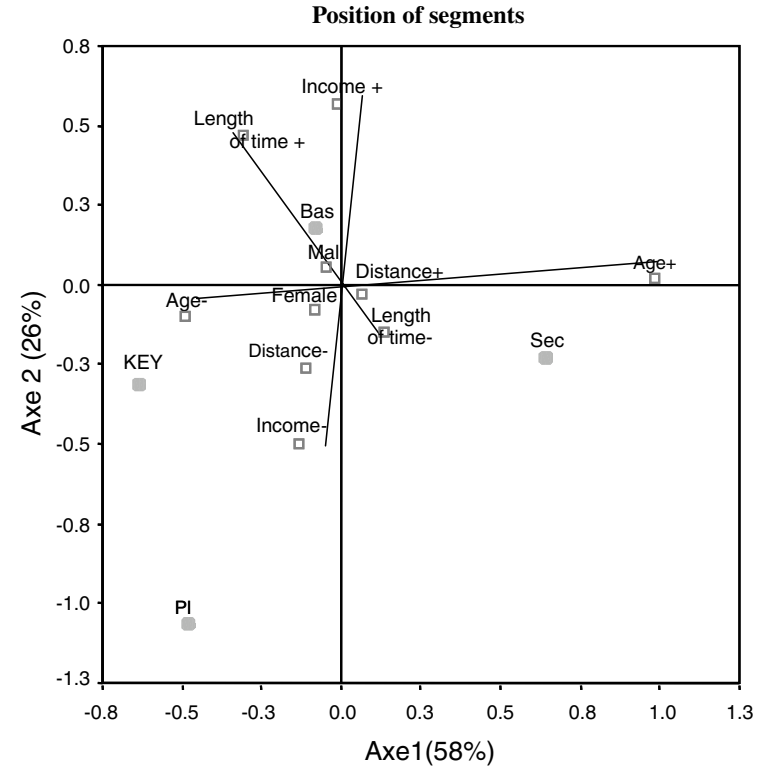

Figure 2: Position of segments

\section{Hypothesis 6 test (the variability of the tetra-class categorisation depends on the nature of the service)}

Appendix A displays, for each service, the number of differences of categorisation with respect to the five segment variables. The values go from 0 , where there is no difference (in this case, the categories remain unchanged for all segments), up to 5, where for each segment variable there is a different category of service.

Analysis of Appendix A shows six levels of category variability between the five segments. The services that show the greatest variability are linked to the information available in the clinic and to the time the client spends in the waiting area. The services that show little variation are linked to the contact personnel according to Eiglier and Langeard, ${ }^{25}$ (thus receptionists, nurses and veterinary surgeons). Table 12 gives the mean degree of variation for each of the nine main categories of service. 
Table 10: Tetra-class categorisation (symmetrical normalisation)

\begin{tabular}{|c|c|c|c|c|c|c|}
\hline \multirow[b]{2}{*}{$\begin{array}{l}\text { Contribution } \\
\text { to satisfaction }\end{array}$} & \multicolumn{3}{|c|}{$\begin{array}{l}\text { Contribution of dimension point } \\
\text { of inertia of dimension }\end{array}$} & \multicolumn{2}{|c|}{$\begin{array}{l}\text { Contribution of dimension } \\
\text { to inertia of point }\end{array}$} & \multirow[b]{2}{*}{ Total } \\
\hline & Inertia & 1 & 2 & 1 & 2 & \\
\hline BAS & 0.003 & 0.032 & 0.246 & 0.203 & 0.686 & 0.889 \\
\hline KEY & 0.009 & 0.272 & 0.094 & 0.584 & 0.089 & 0.673 \\
\hline PLU & 0.008 & 0.075 & 0.541 & 0.182 & 0.585 & 0.767 \\
\hline SEC & 0.013 & 0.621 & 0.119 & 0.902 & 0.076 & 0.979 \\
\hline Active total & 0.032 & 1.000 & 1.000 & & & \\
\hline
\end{tabular}

Table 11: Contribution of segments (symmetrical normalisation)

\begin{tabular}{|c|c|c|c|c|c|c|}
\hline \multirow[b]{2}{*}{$\begin{array}{l}\text { Five segments } \\
\text { dichotomised }\end{array}$} & \multirow[b]{2}{*}{ Inertia } & \multicolumn{2}{|c|}{$\begin{array}{l}\text { Contribution of dimension to } \\
\text { point of inertia }\end{array}$} & \multicolumn{2}{|c|}{$\begin{array}{l}\text { Contribution of dimension to } \\
\text { inertia of point }\end{array}$} & \multirow[b]{2}{*}{ Total } \\
\hline & & 1 & 2 & 1 & 2 & \\
\hline$<50$ years & 0.004 & 0.176 & 0.011 & 0.889 & 0.023 & 0.912 \\
\hline$>50$ years & 0.013 & 0.710 & 0.001 & 1.000 & 0.000 & 1.000 \\
\hline-5 years & 0.003 & 0.013 & 0.024 & 0.097 & 0.078 & 0.175 \\
\hline+5 years & 0.003 & 0.068 & 0.242 & 0.374 & 0.588 & 0.962 \\
\hline$<5$ miles & 0.002 & 0.009 & 0.076 & 0.079 & 0.281 & 0.360 \\
\hline$>5$ miles & 0.000 & 0.003 & 0.001 & 0.897 & 0.101 & 0.998 \\
\hline$<1500 \$$ & 0.003 & 0.013 & 0.278 & 0.091 & 0.863 & 0.954 \\
\hline$>1500 \$$ & 0.003 & 0.000 & 0.358 & 0.001 & 0.910 & 0.911 \\
\hline Female & 0.000 & 0.005 & 0.007 & 0.257 & 0.153 & 0.410 \\
\hline Male & 0.001 & 0.002 & 0.003 & 0.051 & 0.041 & 0.091 \\
\hline Active total & 0.032 & 1.000 & 1.000 & & & \\
\hline
\end{tabular}

Table 12: Category variability according to the type of service

\begin{tabular}{|c|c|c|c|c|c|}
\hline Type of service & $N$ & Mean & $\begin{array}{l}\text { Standard } \\
\text { deviation }\end{array}$ & Min & Max \\
\hline Information & 13 & 3.38 & 1.76 & 0 & 5 \\
\hline Waiting & 19 & 3.37 & 1.57 & 0 & 5 \\
\hline Access & 4 & 2.75 & 1.71 & 1 & 5 \\
\hline End of visit & 4 & 2.50 & 1.92 & 1 & 5 \\
\hline Telephone & 5 & 1.40 & 2.19 & 0 & 5 \\
\hline Exterior & 4 & 1.00 & 1.41 & 0 & 3 \\
\hline Hospitalisation & 7 & 0.71 & 1.25 & 0 & 3 \\
\hline Support staff & 15 & 0.60 & 1.12 & 0 & 4 \\
\hline Veterinary & 21 & 0.29 & 0.78 & 0 & 3 \\
\hline Total & 92 & 1.74 & 1.91 & 0 & 5 \\
\hline
\end{tabular}

The hypothesis of equality of mean values is rejected with a risk level of 1 per cent, which therefore validates hypothesis 6 (Table 13).

Bonferroni's pair comparison test (which tests, under the hypothesis of homogeneous variances, the statistical significance of each difference between paired means) shows that only six pairs of services are statistically different from the point of view of variability of classification:
- Support staff versus waiting and support staff versus information.

- Hospitalisation versus waiting and veterinary versus waiting.

- Hospitalisation versus information and veterinary versus information.

These results show that the services that constitute the main service (ie veterinary, support 
Table 13: Results of the ANOVA

\begin{tabular}{llrlll}
\hline Variability & Sum of squares & df & Mean square & $\boldsymbol{F}$ & Sig. \\
\hline Between groups & 165.977 & 8 & 20.747 & 10.388 & 0.000 \\
Within groups & 165.762 & 83 & 1.997 & & \\
Total & 331.739 & 91 & & & \\
\hline
\end{tabular}

Table 14: Mean tetra-class category variability of services between client segment variants

\begin{tabular}{lll}
\hline Class & $\begin{array}{l}\text { Mean category } \\
\text { variability } \\
\text { between segment } \\
\text { variables }\end{array}$ & $\begin{array}{l}\text { Size of the } \\
\text { class }\end{array}$ \\
\hline 1 & 2.14 & 30 \\
2 & 4.42 & 22 \\
3 & 0.15 & 40 \\
Overall mean & 1.74 & 92 \\
\hline
\end{tabular}

staff and hospitalisation) are nearly always classified in the same way (ie 'Basic'), irrespective of the client segment is analysed. On the contrary, the services that constitute the peripheral service (information, waiting, access) are those whose tetra-class category varies the most from one segment to another.

\section{Hypothesis 7 test (typology of services according to the extent of their category variability)}

The category variability of services relative to client segments (Table 1 ) can be coded by accordingly, by service and segment variable, the value 1 in case of a difference in categorisation, and the value 0 in case of a similar categorisation. Each service is therefore giving a five figure binary score, characterising its category variability for each of the five segment variables (in the following order: age, time with clinic, distance, income, gender). For example, the service 'ac-fac: Ease + proximity of parking' will be allocated the code 00010, as it has only one difference in categorisation - for the variable 'income'.

In order to regroup the most similar services into classes that show the greatest differentiation, we have used an ascending hierarchical classification of binary values, applying Ward's aggregation method and choosing the square of the Euclidean distance. The result is displayed in a hierarchical tree (Appendix D).

The results clearly demonstrate the existence of three separate classes of services, which we have displayed in Appendix A. Class 2 (upper part of the hierarchical tree) brings together those services that are linked to information available in the clinic.

Class 3 (central part of the tree) consists of those services that involve staff contact with the client. Class 1 (lower part of the tree) is made up of those services that seem to be involved with the notion of 'taking care of the client'.

In its conception, the hierarchical tree has created the three classes of services that differ the most in terms of their tetra-class category variability. The variability of each service having been quantified on a scale from 0 (no variation) to 5 (maximal variation), and the average scores for each class of service were calculated as shown in Table 14.

The difference between the three means was tested for significance using variance analysis $(F=321.277$ and sig. $=0.000)$. This therefore supports hypothesis $\mathrm{H} 7$. We can also add that the services for which the tetra-class categorisation was the most stable are those connected to 'staff in contact' (class 3, which has a mean variability score of 0.15 out of 5). The most unstable services in terms of Llosa's model of categorisation are those linked to the waiting area and information available on site (class 2 with a mean score of 4.42 out of 5 ).

\section{CONCLUSION}

The main results of this research indicate that different services show tetra-class category variability to a greater or lesser degree. This variability, however, does not nullify the tetra-class model, as it only affects a minority of services.

Among the five segment variables that were analysed (age, time with the clinic, distance, income and gender), the greatest number of service category variables were found to be linked 
to the income of the client and their distance from the clinic. The managerial implication of this study is that before any hasty strategic conclusions can be made about what improvements are necessary for services in a given client segment, careful consideration of the relevant client segments and multiples thereof is vital.

When we analyse the category variability for all the client segments combined, we observe strong differences according to the type of service offered. The category variability is weak for services of technical nature, which constitute the central service. These services contribute to overall satisfaction in a basic way. The services involved with information, waiting and access show a greater category variation. These are peripheral services. Their greater category variation could be due to the difficulties in evaluating these services. The managerial implication here is to apply a client segment analysis when it concerns the peripheral services.

Finally, the topographical analysis confirms the previous result; the category variability of services is the least significant for those that involve staff contact and the most significant for those linked to peripheral services and material support of services.

Our further studies will concentrate on the limits of this research: it will be important to duplicate the method of analysis by client segment in other service sectors to ensure a similarity of results and the stability of the tetra-class classification. Results obtained in the health sector, with its strong client involvement, cannot allow generalisations to be made for other service sectors.

\section{References}

1 Brown, S. W. and Swartz, T. A. (1989) 'A gap analysis of professional service quality', Journal of Marketing, Vol. 53, (April), pp. 92-98.

2 Parasuraman, A., Zeithalm, V. and Berry, L. (1988) 'SERVQUAL: A multiple-item scale for measuring consumer perceptions of service quality', Journal of Retailing, Vol. 64, pp. 12-40.

3 Rudie, M. J. and Wansley, H. B. (1985) 'The Merryl Lynch quality program', In Services Marketing, American Marketing Association, (eds), AMA, Chicago.

4 Cadotte, E. R., Woodruff, R. B. and Jenkins, R. L. (1987) 'Expectations and norms in models of consumer satisfaction', Journal of Marketing Research, Vol. 24, pp. 305-314.

5 Cronin, J. J. and Taylor, S. A. (1992) 'Measuring service quality: A reexamination and extension', Journal of Marketing, Vol. 56, pp. 55-68.
6 Audrain, A. -F. and Evrard, Y. (2001) 'Satisfaction des consommateurs: Précisions conceptuelles. Actes de la Conférence de l'Association Française du Marketing', IAE de Caen-Basse Normandie, Deauville.

7 Bitner, M. J. (1990) 'Evaluating service encounters: The effects of physical surroundings and employee responses', Journal of Marketing, Vol. 54, pp. 69-82.

8 Bolton, R. N. and Drew, J. H. (1991) 'A longitudinal analysis of the impact of service changes on customer attitudes', Journal of Marketing, Vol. 55, pp. 1-9.

9 Garbarino, E. and Johnson, M. S. (1999) 'The different roles of satisfaction, trust, and commitment in customer relationships', Journal of Marketing, Vol. 63, pp. 70-87.

10 Cadotte, E. R. and Turgeon, N. (1988) 'Dissatisfiers and satisfiers: Suggestions for consumer complaints and compliments', Journal of Consumer Satisfaction, Dissatisfaction and Complaining Behavior, Vol. 1, pp. 74-79.

11 Swan, J. and Combs, J. (1976) 'Product performance and consumer satisfaction: A new concept', Journal of Marketing, Vol. 40, pp. 25-33.

12 Herzberg, F., Mausner, B. and Snyderman, B. (1959). The Motivation to Work', John Wiley and Sons, Inc, New York.

13 Llosa, S. (1997) 'L'analyse de la contribution des éléments du service à la satisfaction: un modèle tétra-classe', Décisions Marketing, Vol. 10, pp. 81-88.

14 Llosa, S. (1996) 'Contributions à l'étude de la satisfaction dans les services. Thèse de Doctorat en Sciences de Gestion', I.A.E., Aix-Marseille.

15 Bartikowski, B. and Llosa, S. (2001) 'De la théorie du poids fluctuant des éléments dans la satisfaction à la mesure. Comparaison empirique de quatre méthodes, Actes de la Conférence de l'Association Française du Marketing', IAE de Caen-Basse Normandie, Deauville.

16 Llosa, S. (1997). op. cit.

17 Lichtlé, M. -C., Plichon, V. and Llosa, S. (2001) 'La contribution des éléments d'une grande surface alimentaire à la satisfaction du client. Actes de la Conférence de l'Association Française du Marketing', IAE de Caen-Basse Normandie, Deauville.

18 Clerfeuille, F. and Poubanne, Y. (2003) 'Differences in the contributions of elements of service to satisfaction, commitment and consumer's share of purchase: a study from the tetraclass model', Journal of Targeting, Measurement and Analysis for Marketing, Vol. 12, No. 1, pp. 66-81.

19 Poubanne, Y. and Clerfeuille, F. (2002) 'Contribution des éléments de service à la satisfaction des consommateurs: la nécessaire prise en compte de variables de segmentation', XVI èmes journées nationales des I.A.E., Paris, 10-12 Septembre 2002.

20 Homburg, C. and Giering, A. (2001) 'Personal characteristics as moderators of the relationship between customer satisfaction and loyalty — an empirical analysis', Psychology \& Marketing, Vol. 18, No. 1, pp. 43-66.

21 Mittal, V. and Kamakura, W. A. (2001) 'Satisfaction, repurchase intent, and repurchase behavior: Investigating the moderating effect of customer characteristics', Journal of Marketing Research, Vol. 38, pp. 131-142.

22 Llosa, S. (1996). op. cit.

23 Breiman, L., Friedman, J. H., Olshen, R. A. and Stone, C. J. (1984). Classification and Regression Trees', Wadsworth, Belmont, California.

24 Llosa, S. (1996). op.cit.

25 Eiglier, P. and Langeard, E. (1988). Servuction, Le marketing des services', McGraw-Hill, Paris. 


\section{Appendix A}

List of the 92 services used in this study, each with its level of category variability (0-5) and its class of category variation (1-3)

\begin{tabular}{|c|c|c|c|}
\hline Abbr. & Description of service & Level (0-5) & Class (1-3) \\
\hline ac-ind & Access: signs indicating the way to the clinic & 5 & 2 \\
\hline fi-rqp & Financial: price versus quality of the clinic & 5 & 2 \\
\hline in-acq & Information: re acquirng a pet & 5 & 2 \\
\hline in-ele & Information: re training my pet & 5 & 2 \\
\hline in-pro & Information: re products sold in the clinic & 5 & 2 \\
\hline in-spe & Information: specialisations available at the clinic & 5 & 2 \\
\hline te-dec & Telephone: speed of response & 5 & 2 \\
\hline at-sie & Waiting area: availability of chairs & 5 & 2 \\
\hline at-enf & Waiting area: special area for children & 5 & 2 \\
\hline at-pro & Waiting area: cleanliness & 5 & 2 \\
\hline at-dec & Waiting area: decor & 5 & 2 \\
\hline at-del & Waiting area: information about delays & 5 & 2 \\
\hline at-tmp & Waiting area: temperature & 5 & 2 \\
\hline in-sai & Information: breeding from my pet & 4 & 2 \\
\hline in-mor & Information: re the death of my pet & 4 & 2 \\
\hline in-inf & Information: personnal information & 4 & 2 \\
\hline in-nou & Information: re new products and services & 4 & 2 \\
\hline as-bad & Staff: whether they wear name badges & 4 & 2 \\
\hline at-inf & Waiting area: information on products and services & 4 & 2 \\
\hline at-rev & Waiting area: magazines available & 4 & 2 \\
\hline in-gar & Information: re kennels and boarding for my pet & 4 & 1 \\
\hline at-iso & Waiting area: possibility to get away from other clients & 4 & 1 \\
\hline at-tem & Waiting area: time spent waiting & 4 & 1 \\
\hline ho-vis & Hospitalisation: opportunity to visit the animal & 3 & 2 \\
\hline at-mus & Waiting area: ambient music & 3 & 2 \\
\hline ac-rap & Access: ease and speed of access to the clinic & 3 & 1 \\
\hline ex-spe & Exterior: Indication of names and specialisations of vets & 3 & 1 \\
\hline fi-dev & Financial: quote before treatment / hospitalisation & 3 & 1 \\
\hline ve-cho & Veterinary: see the veterinary surgeon of my choice & 3 & 1 \\
\hline at-con & Waiting area: comfort of chairs & 3 & 1 \\
\hline at-tab & Waiting area: notice board with small ads & 3 & 1 \\
\hline at-pon & Waiting area: punctuality & 3 & 1 \\
\hline ac-sec & Access: safety of car park for my animal & 2 & 1 \\
\hline ho-con & Hospitalisation: the animal's comfort & 2 & 1 \\
\hline in-ass & Information: re pet insurance & 2 & 1 \\
\hline as-dos & Staff: access to the clinical records of my animal & 2 & 1 \\
\hline te-dis & Telephone: ease of getting through & 2 & 1 \\
\hline ve-con & Veterinary: advice about the health of my pet & 2 & 1 \\
\hline at-occ & Waiting room: things to do & 2 & 1 \\
\hline at-clar & Waiting area: lighting of the waiting room & 2 & 1 \\
\hline ac-fac & Access: ease of parking close to the clinic & 1 & 1 \\
\hline ex-ass & Exterior: possibility of waiting outside & 1 & 1 \\
\hline fi-cla & Financial: clarity of the bill & 1 & 1 \\
\hline fi-exp & Financial: explications at the time of payment & 1 & 1 \\
\hline in-per & Information: lost animals & 1 & 1 \\
\hline in-voy & Information: travelling with my pet & 1 & 1 \\
\hline as-eco & Staff: ability to listen & 1 & 1 \\
\hline as-amo & Staff: love of animals & 1 & 1 \\
\hline as-sou & Staff: smiles & 1 & 1 \\
\hline ve-amo & Veterinary: love of animals & 1 & 1 \\
\hline at-aff & Waiting area: posters & 1 & 1 \\
\hline at-ode & Waiting area: odour of the waiting area & 1 & 1 \\
\hline ex-pro & Exterior: cleanliness of the entrance area & 0 & 3 \\
\hline ex-heu & Exterior: clear indication of opening and closing times & 0 & 3 \\
\hline ho-cla & Hospitalisation: clarity of discharge instructions & 0 & 3 \\
\hline ho-sui & Hospitalisation: follow up of the case & 0 & 3 \\
\hline ho-ras & Hospitalisation: reassurance & 0 & 3 \\
\hline ho-nou & Hospitalisation: updates by phone & 0 & 3 \\
\hline ho-evo & Hospitalisation: updates about my pets health & 0 & 3 \\
\hline in-ser & Information: re services offered by the clinic & 0 & 3 \\
\hline as-aff & Staff: affection towards my pet & 0 & 3 \\
\hline as-pre & Staff: always available at reception & 0 & 3 \\
\hline as-ten & Staff: appropriate and clean clothing & 0 & 3 \\
\hline
\end{tabular}


Appendix A: Continued

\begin{tabular}{|c|c|c|c|}
\hline Abbr. & Description of service & Level (0-5) & Class (1-3) \\
\hline as-com & Staff: commercial competence & 0 & 3 \\
\hline as-int & Staff: interest in my animal & 0 & 3 \\
\hline as-dou & Staff: kindness towards my pet & 0 & 3 \\
\hline as-pat & Staff: patience & 0 & 3 \\
\hline as-pol & Staff: politeness & 0 & 3 \\
\hline as-ras & Staff: reassurance & 0 & 3 \\
\hline as-tec & Staff: technical competence & 0 & 3 \\
\hline te-rap & Telephone: call me back if not available & 0 & 3 \\
\hline te-clar & Telephone: clarity of answers to my questions & 0 & 3 \\
\hline te-rdv & Telephone: getting a convenient consultation time & 0 & 3 \\
\hline ve-pro & Veterinary: cleanliness & 0 & 3 \\
\hline ve-aff & Veterinary: affection for my pet & 0 & 3 \\
\hline ve-com & Veterinary: commercial competence & 0 & 3 \\
\hline ve-dec & Veterinary: interest to help me decide & 0 & 3 \\
\hline ve-dev & Veterinary: devotion to my animal & 0 & 3 \\
\hline ve-dia & Veterinary: accuracy of diagnosis & 0 & 3 \\
\hline ve-sou & Veterinary: pleasant disposition & 0 & 3 \\
\hline ve-exp & Veterinary: clarity of explanations & 0 & 3 \\
\hline ve-dou & Veterinary: gentle ness with my animal & 0 & 3 \\
\hline ve-hon & Veterinary: honesty & 0 & 3 \\
\hline ve-int & Veterinary: interest in my pet & 0 & 3 \\
\hline ve-arg & Veterinary: balance between money and love for animal & 0 & 3 \\
\hline ve-pol & Veterinary: politeness & 0 & 3 \\
\hline ve-rass & Veterinary: reassurance & 0 & 3 \\
\hline ve-gue & Veterinary: speed of recovery of my pet & 0 & 3 \\
\hline ve-rap & Veterinary: speed of diagnosis & 0 & 3 \\
\hline ve-tec & Veterinary: technical competence & 0 & 3 \\
\hline ve-tem & Veterinary: time spent in consultation & 0 & 3 \\
\hline at-bru & Waiting area: noise levels & 0 & 3 \\
\hline
\end{tabular}

\section{Appendix B}

Sample characteristics

\begin{tabular}{|c|c|c|c|}
\hline Variable & Modalities & Frequency & Percentage \\
\hline Age & $\begin{array}{l}\text { Less than } 20 \text { years } \\
20-29 \text { years } \\
30-39 \text { years } \\
40-49 \text { years } \\
50-59 \text { years } \\
60 \text { years and over }\end{array}$ & $\begin{array}{l}3 \\
40 \\
58 \\
73 \\
58 \\
35\end{array}$ & $\begin{array}{l}1.1 \\
15.0 \\
21.7 \\
27.3 \\
21.7 \\
13.1\end{array}$ \\
\hline Gender & $\begin{array}{l}\text { Male } \\
\text { Female }\end{array}$ & $\begin{array}{l}63 \\
204\end{array}$ & $\begin{array}{l}23.6 \\
76.4\end{array}$ \\
\hline Income (monthly) & $\begin{array}{l}\text { Under } 1500 \$ \\
1500-3000 \$ \\
3000-4500 \$ \\
\text { More than } 4500 \$\end{array}$ & $\begin{array}{l}82 \\
106 \\
47 \\
32\end{array}$ & $\begin{array}{l}30.7 \\
39.7 \\
17.6 \\
12.0\end{array}$ \\
\hline Distance & $\begin{array}{l}\text { Less than } 1 \text { mile } \\
1-5 \text { miles } \\
6-10 \text { miles } \\
\text { More than } 10 \text { miles }\end{array}$ & $\begin{array}{l}55 \\
108 \\
55 \\
49\end{array}$ & $\begin{array}{l}20.6 \\
40.4 \\
20.6 \\
18.4\end{array}$ \\
\hline Time with clinic & $\begin{array}{l}1 \text { year } \\
2 \text { years } \\
3 \text { years } \\
4 \text { years } \\
5 \text { years }+\end{array}$ & $\begin{array}{l}25 \\
24 \\
42 \\
23 \\
153\end{array}$ & $\begin{array}{l}9.4 \\
9.0 \\
15.7 \\
8.6 \\
57.3\end{array}$ \\
\hline
\end{tabular}




\section{Appendix C}

Categorisation of services for the client segment variable 'Age'

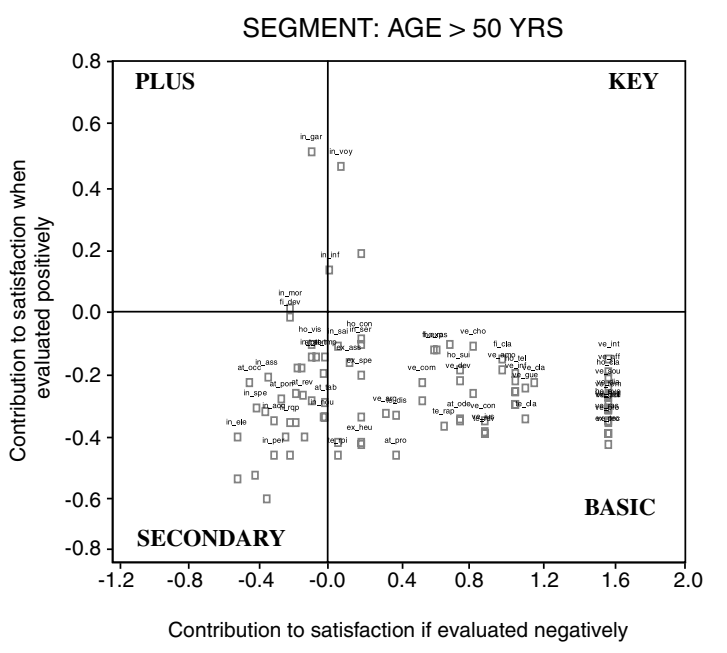

SEGMENT: AGED UNDER 50 YRS

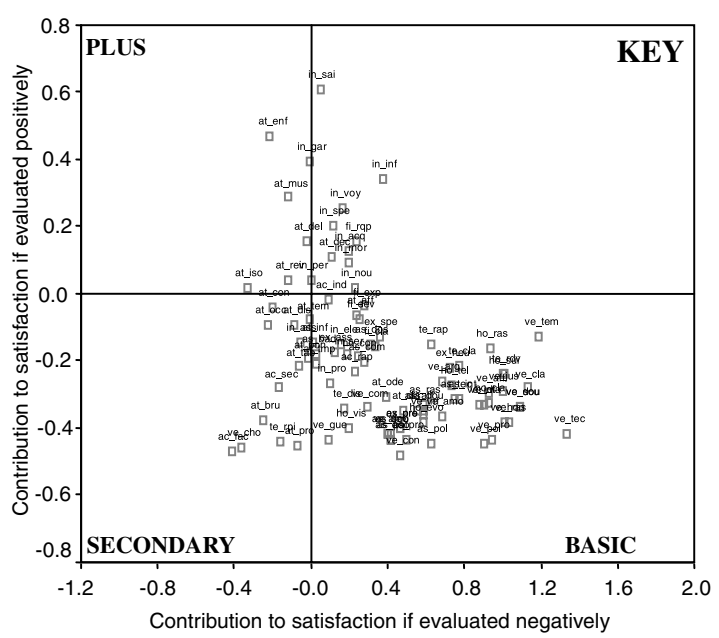

\section{Appendix D}

Hierarchical tree

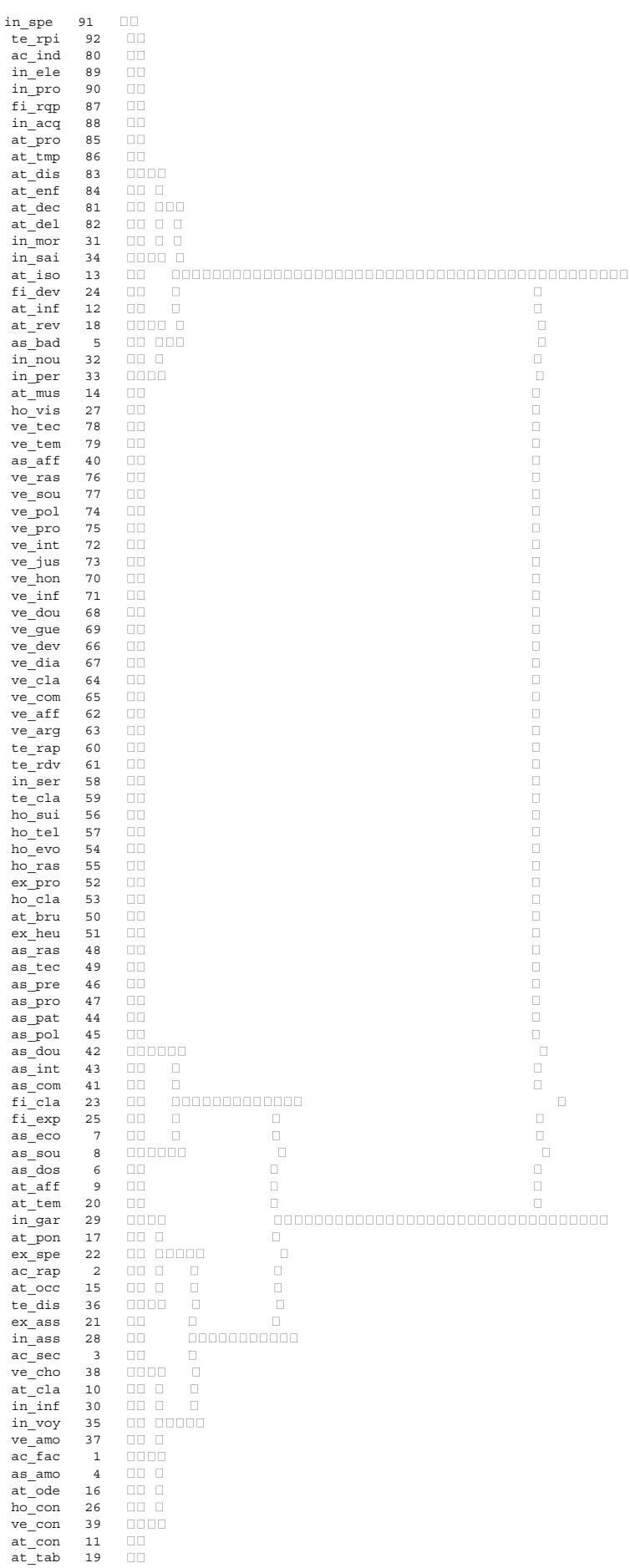

